\title{
Novel isoform of adaptor protein ITSN1 forms homodimers via its C-terminus
}

\author{
M. V. Dergai, O. V. Dergai, L. O. Tsyba, O. V. Novokhatska, I. Ya. Skrypkina,
}

\section{A. V. Rynditch}

Institute of Molecular Biology and Genetics, NAS of Ukraine

150, Akademika Zabolotnoho Str., Kyiv, Ukraine, 03680

m.dergai@gmail.com

\begin{abstract}
Aim. Previously we have identified a novel isoform of endocytic adaptor protein ITSN1 designated as ITSN122a. Western blot revealed two immunoreactive bands of 120 and $250 \mathrm{kDa}$ that corresponded to ITSN1-22a. The goal of this study was to investigate the possibility of dimer formation by the novel isoform. Methods. Dimerization ability of ITSN1-22a was tested by immunoprecipitation and subsequent Western blot analysis. To specify the region responsible for dimerization, site-directed mutagenesis and truncation analysis were carried out. Inhibition of endocytosis by potassium depletion and EGF stimulation of HEK293 were performed. Results. We have found that ITSN1-22a forms dimers in HEK293 cells. The dimerization of ITSN1-22a was mediated by C-terminal domain. We showed that cysteines C1016 and C1019 were involved in homodimerization. Inhibition of clathrin-mediated endocytosis and mitogen stimulation did not affect ITSN1-22a dimer formation. Conclusions. ITSN1-22a is the only one known ITSN1 isoform, which is capable to form homodimers via disulphide bonds. This could be important for the formation of protein complexes containing ITSN1 molecules.
\end{abstract}

Keywords: intersectin 1, isoform, homodimer.

Introduction. Intersectin 1 (ITSN1) is a widely expressed cytosolic, multidomain scaffold protein, which is conserved from worms to humans. This protein coordinates several pathways controlling clathrin-mediated endocytosis as well as exocytosis.

Initially the role of ITSN1 in endocytosis was demonstrated at invagination and fission stages [1,2]. Recently, ITSN1 has been shown to participate in other processes including the determination of cell polarity, cell cycle progression [3], mitogenic signalling [4] and cell survival [5] through the activation of the PI3KAKT pathway [5].

Previously, two major ITSN1 isoforms were described: the ubiquitously expressed short isoform (ITSN1s) and the long isoform (ITSN1-1), which are predomi-

(C) Institute of Molecular Biology and Genetics, NAS of Ukraine, 2011 nantly expressed in brain [6]. ITSN1-s possesses two EH (Eps15 homology) domains at the N-terminus, followed by a coiled-coil region (CCR) and five $\mathrm{SH} 3$ domains (Src homology domains A-E). ITSN1-1 additionally contains a $\mathrm{C}$-terminal extension consisting of a conserved tandem DH (Dbl homology) and PH (Plekstrin homology) domains, and a C2 domain [6]. Protein interactions of these ITSN1 isoforms were extensively studied during last decade (reviewed in [7]). Splicing affecting 5' UTR of ITSN1 transcripts was also shown [8].

Recently we have identified a novel isoform of ITSN1 that possess unique $\mathrm{C}$-terminal domain instead of four last $\mathrm{SH} 3$ domains on its C-terminus [9]. This isoform is produced by inclusion of the alternative exon 22a. ITSN1-22a migrated in SDS-PAGE as two immunoreactive bands. Here we report that recently identifi- 
ed isoform ITSN1-22a forms homodimers via the C-terminal domain.

Materials and methods. Antibodies. Polyclonal antibodies against the EH2 domain of ITSN1 [10] and anti-CTD antibodies [9] were described previously. Monoclonal anti-Omni (D-8, sc-7270) antibody was purchased from «Santa Cruz Biotechnology» (USA).

DNA constructs. Constructs encoding OmniITSN1-22a, Omni-ITSN1-22a $\triangle 86$, GST-SH3A-CTD and GST-SH3A-CTD $\Delta 39$ were described previously [9]. Site-directed mutagenesis was carried out with reverse primer 5 '-atgcggccgctcacaagtaatggggaagaGC gagataaaaaGCaccaa-3'.

Protein expression, pull-down assays and Western blot analysis were conducted as described previously [9].

Cell culture and transfection. HEK293 cells were maintained in Dulbecco's modified Eagle's medium (DMEM) supplemented with $10 \%$ fetal calf serum, 50 $\mathrm{U} / \mathrm{ml}$ penicillin and $100 \mu \mathrm{g} / \mathrm{ml}$ streptomycin. The cells were transiently transfected using polyethylenimine transfection reagent (JetPEI, Polyplus Transfection) and processed 24 to $36 \mathrm{~h}$ after transfection.

Immunoprecipitation. For immunoprecipitation (IP) cells were lysed in IP buffer $(20 \mathrm{mM}$ Tris- $\mathrm{HCl} \mathrm{pH}$ $7.5,0.5 \% \mathrm{NP} 40,100 \mathrm{mM} \mathrm{NaCl}, 10 \%$ glycerol, $1 \mathrm{mM}$ PMSF and protease inhibitor cocktail). HEK293 cell lysate was mixed with antibodies and protein A/G. After overnight incubation at $4{ }^{\circ} \mathrm{C}$ the beads were washed three times with IP buffer. Bound proteins were eluted by boiling in Laemmli sample buffer and analysed by SDS-PAGE and Western blot.

Inhibition of endocytosis. Endocytosis was inhibied by potassium depletion [10]. Cells were washed twice with depletion buffer (20 mM HEPES, $\mathrm{pH}$ 7.4, $0.14 \mathrm{M} \mathrm{NaCl}, 1 \mathrm{mM} \mathrm{CaCl}_{2}, 1 \mathrm{mM} \mathrm{MgCl}_{2}$, and $1 \mathrm{~g} / 1 \mathrm{D}-$ glucose). Subsequently, the cells were incubated for 5 min with a hypotonic buffer consisting of one part depletion buffer and one part $\mathrm{H}_{2} \mathrm{O}$. Then, the cells were incubated for a further $30 \mathrm{~min}$ in depletion buffer at $37^{\circ} \mathrm{C}$. Control cells were incubated with the same buffer supplemented with $10 \mathrm{mM} \mathrm{KCl}$.

Results and discussion. To investigate functional features of ITSN1-22a isoform, a construct encoding Omni-tagged ITSN1-22a (Fig. 1, $A$ ) was expressed in HEK293 cells. Western blot analysis of ITSN1-22a im-

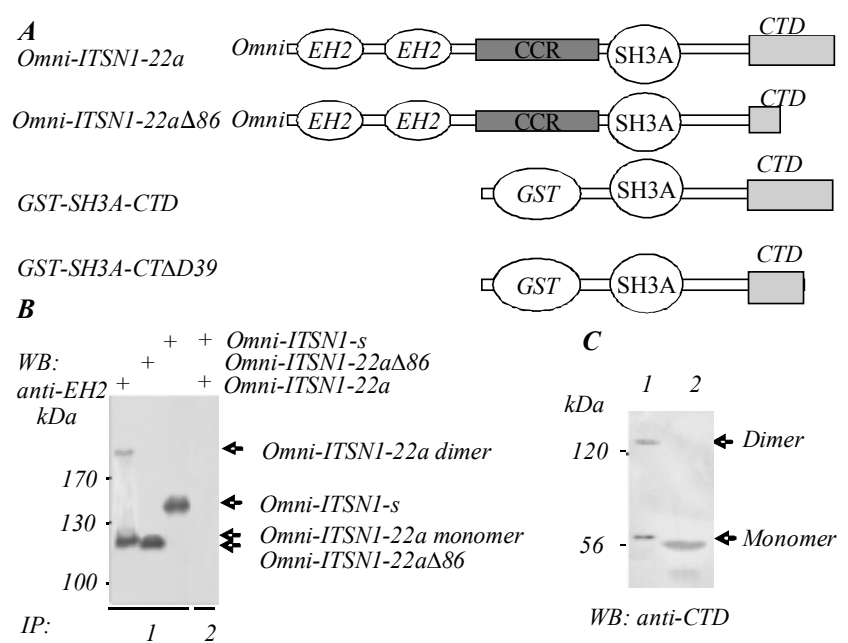

Fig. 1. Novel isoform of ITSN1 adaptor forms dimer in vivo: $A-$ schematic representation of recombinant proteins used in this study; $B$ - HEK293 cells expressing Omni-ITSN1-s, Omni-ITSN1-22a and ITSN1-22a $\Delta 86$ were lysed $24 \mathrm{~h}$ after transfection; cell lysates were subjected to immunoprecipitation with anti-Omni antibody or normal mouse serum (NMS) as a negative control followed by immunobloting with anti-EH2 antibodies; $C-$ GST-SH3A-CTD and GST-SH3ACTD $\Delta 39$ were expressed in E. coli and affinity purified; recombinant proteins were immunoblotted with anti-CTD antibodies

munoprecipitates obtained with anti-Omni antibody revealed a major band of $116 \mathrm{kDa}$ and an additional band of approximately doubled size $(250 \mathrm{kDa})$. In similar experiments performed with ITSN1 short isoform, OmniITSN1-s appeared as a single band with the expected molecular weight of $136 \mathrm{kDa}$ (Fig. 1, $B$ ). At the same time truncated Omni-ITSN1-22a $\Delta 86$ mutant $(110 \mathrm{kDa})$ lacking the last 86 amino acids did not produce band of higher molecular weight (Fig. 1, B). From this observation we assumed that ITSN1-22a is able to form dimers. However, it was not clear weather ITSN-22a forms homodimer or heterodimer with other protein of similar molecular weight. To exclude the presence of eukaryotic cell components we expressed the C-terminal region of ITSN1-22a in Escherichia coli. The GSTfusion protein containing SH3A domain and the C-terminal domain of ITSN1-22a (GST-SH3A-CTD) was purified from $E$. coli and visualized in Western blot as two bands with apparent molecular weight of 60 and $120 \mathrm{kDa}$ (Fig. 1, C). Given that the bacterially expressed C-terminal part of ITSN1-22a was able to produce dimer we suggested that homodimerization occurs rather than heterodimerization. To specify more precisely region engaged in dimerization we prepared truncated form of GST-SH3A-CTD lacking 39 residues at 

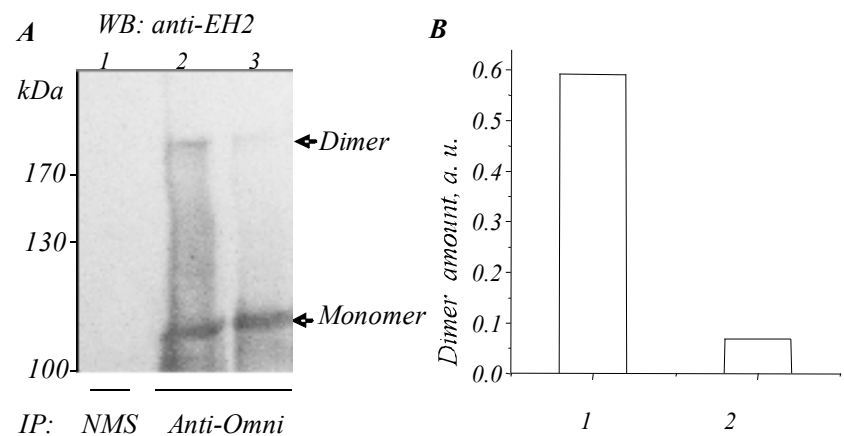

Fig. 2. Disulphide bonds within ITSN1-22a mediate homodimerization: $A$ - HEK293 cells expressing Omni-ITSN1-22a $(1,2)$ or ITSN1-22aCA(3) were lysed $24 \mathrm{~h}$ after transfection; recombinant proteins were precipitated with anti-Omni antibody with subsequent Western blot with anti-EH2 antibodies; $B$-diagram demonstrates the amount of dimer of ITSN1-22a(1) and ITSN1-22aCA (2) normalized to corresponding monomer; densitometric analysis was performed with ImageJ software
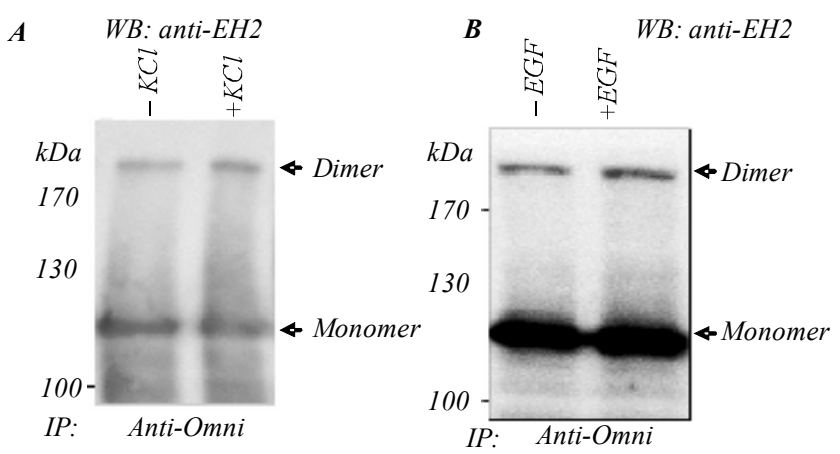

Fig. 3. Dimerization of ITSN1-22a does not depend on clathrin-mediated endocytosis and mitogen stimulation: $A-\mathrm{HEK} 293$ cells expressing Omni-ITSN1-22a were treated to inhibit clathrin-mediated endocytosis $(-\mathrm{KCl})$ or recover this process $(+\mathrm{KCl})$; precipitated with antiOmni antibody recombinant ITSN1-22a was subjected to Western blot with anti-EH2 antibodies; $B$ - immunoblotting of precipitated with anti-Omni antibody Omni-tagged ITSN1-22a from mitogen-starved (- EGF) and stimulated with $50 \mathrm{ng} / \mathrm{ml} \mathrm{EGF} \mathrm{(+} \mathrm{EGF)} \mathrm{HEK293} \mathrm{cells.}$ Cells were mitogen-starved for $12 \mathrm{~h}$ and then stimulated by growth factor for $10 \mathrm{~min}$

C-terminus (SH3A-CTD $\triangle 39$ ). Western blot analysis demonstrated that SH3A-CTD 39 did not form dimers (Fig. 1, C). Thus, the C-terminal residues of ITSN1-22a are supposed to be responsible for the formation of homodimers.

We suggested that disulphide bonds could be engaged in homodimerization of ITSN1-22a. Non-covalent protein-protein interactions are unlikely given that ITSN1-22a dimer sustained prolonged boiling. Boiling of ITSN1-22a with mercaptoethanol during $30 \mathrm{~min}$ did not affected the amount of dimer significantly reducing it less than in $20 \%$ of cases (data not shown). Homo- dimers formed by disulphide bonds could be extremely stable against mercaptoethanol [11-13]. Three cysteines were found within $39 \mathrm{C}$-terminal residues that contained clustering signal. The residue $\mathrm{C} 1016$ is conserved in all mammals whereas C990 and C1019 are specific only for primates (data not shown). To assess a possible role of the cysteines C1016 and C1019 in homodimerization, we substituted alanines for these residues (ITSN1-22aCA). Fig. 2 shows that the mutations significantly decreased the amount of dimerized form of ITSN1-22aCA in comparison with wild type ITSN122a. However, these substitutions did not abolish dimerization completely (Fig. 2). Presumably, C990 is also able of forming disulphide bonds, however, its impact on dimerization is moderate in comparison with C1016 and C1019.

We investigated cellular processes in which dimerization could occur. As ITSN1 is a well-established endocytic protein we studied whether the formation of ITSN1-22a dimer depends on the endocytic activity. Our data (Fig. 3, A) indicated that dimerization of ITSN1-22a was not affected by inhibition of endocytosis and disruption of endocytic sites by potassium depletion. The dimerization of ITSN1-22a was also independent on mitogenic stimulation of HEK293 cells with epidermal growth factor (EGF) (Fig. 3, B).

Thus, the obtained data demonstrate that the novel isoform of ITSN1 adaptor ITSN1-22a is capable to form homodimers due to the $\mathrm{C}$-terminal clustering signal. Previously, Guipponi et al. proposed the coiled-coil region of ITSN1 molecule as putative oligomerization signal [14], however, so far there are no published data confirming this interaction. The CTD of ITSN122a is responsible for this isoform homodimerization signal. The dimerization of ITSN1-22a is not regulated during clathrin-mediated endocytosis or signaling from EGFR. The physiological significance of ITSN1-22a dimers remains a challenge for future investigations.

М. В. Дергай, О. В. Дергай, Л. О. Циба, О. В. Новохаџька, I. Я. Скрипкіна, А. В. Риндич

Нова ізоформа адаптерного білка ITSN1 формує гомодимери за посередництвом власного С-кінцевого домену

Резюме

Мета. Раніше нами ідентифіковано нову ізоформу адаптерного білка ITSN1, названу ITSN1-22а. Вестерн-блот аналіз виявив наявність двох імунореактивних смуг 120 і 250 кДа, що відповіда- 
ють ITSN1-22а. Мета иієї роботи полягала у вивченні здатності нової ізоформи формувати димери. Методи. Імунопрециипітаиію і Вестерн-блот аналіз використано для дослідження здатності ізоформи до димеризаиії. Ідентифікацію ділянки, щзо відповідає за формування димерів, здійснювали за допомогою сайтспрямованого мутагенезу та делеційного аналізу. Інгібування ендоцитозу індукували дефіциитом іонів калію. Для мітогенної стимуляиії клітин НЕК293 застосовано епідермальний фактор росту. Результати. Нами виявлено, щуо надекспресована в клітинах HЕК293 ізоформа ITSN1-22а формує димери. Димеризачія обумовлена специфічним для цієї ізоформи С-кінцевим доменом. Нами показано, що иистеїни С1016 і C1019 залучені до процесу гомодимеризації. Інгібування клатрин-опосередкованого ендоцитозу та стимуляція клітин мітогеном не впливають на формування димерів ізоформою ITSN1-22a. Висновки. ITSN1-22a- - ее єдина відома на сьогодні ізоформа ITSN1, здатна утворювати гомодимери за допомогою дисульфідних зв 'язків, щуо може бути важливим для формування ITSN1-вмісних білкових комплексів.

Ключові слова: інтерсектин 1, ізоформа, гомодимер.

Н. В. Дергай, А. В. Дергай, Л. А. Цыьба, О. В. Новохаикая, И. Я. Скрипкина, А. В. Рындич

Новая изоформа адаптерного белка ITSN1 формирует гомодимеры посредством своего С-концевого домена

Резюме

Цель. Ранее мы идентифицировали новую изоформу адаптерного эндочитозного белка ITSN1, названную ITSN1-22a. Вестерн-блот анализ выявил наличие двух иммунореактивных полос 120 и 250 кДа, соответствуюших ITSN1-22а. Цель этой работы состояла в изучении возможности формирования димеров изоформой ITSN1-22a. Методы. Иммунопреципитация и Вестерн-блот анализ использованы для исследования возможности димеризации изоформы. Идентификачию участка, отвечающего за димеризацию, осуществляли с помощью сайт-направленного мутагенеза и делеиионного анализа. Ингибирование эндочитоза индуиировали дефицитом ионов калия. Для митогенной стимуляции клеток применен эпидермальный фактор роста. Результатыл. Нами обнаружено, что сверхэкспрессированная в клетках НЕК293 изоформа ITSN1-22а формирует димеры. Димеризачия изоформы обусловлена ее специфическим С-кониевым доменом. Нами показано, что ичистеины С1016 и С1019 вовлечены в прочесс гомодимеризации. Ингибирование клатрин-опосредованного эндоцитоза и митогенная стимулячия клеток не влияют на формирование димеров изоформой ITSN1-22a. Выводы. ITSN1-22a - это единственная на сегодня изоформа ITSN1, способная образовывать гомодимеры посредством дисульфидных связей, что может быть важно для формирования ITSN1-содержащих белковых комплексов.

Ключевые слова: интерсектин 1, изоформа, гомодимер.

\section{REFERENCES}

1. Sengar A. S., Wang W., Bishay J., Cohen S., Egan S. E. The EH and $\mathrm{SH} 3$ domain Ese proteins regulate endocytosis by linking to dynamin and Eps 15 // EMBO J.-1999.-18, N 5.-P. 1159-1171.

2. Predescu S. A., Predescu D. N., Timblin B. K., Stan R. V., Malik $A$. $B$. Intersectin regulates fission and internalization of caveolae in endothelial cells // Mol. Biol. Cell.-2003.-14, N 12.-P. 49975010.

3. Chabu C., Doe C. Q. Dap160/intersectin binds and activates aPKC to regulate cell polarity and cell cycle progression // Development.-2008.-135, N 16.-P. 2739-2746.

4. Mohney R. P., Das M., Bivona T. G., Hanes R., Adams A. G., Philips M. R., O'Bryan J. P. Intersectin activates Ras but stimulates transcription through an independent pathway involving JNK // J. Biol. Chem.-2003.-278, N 47.-P. 47038-47045.

5. Das M., Scappini E., Martin N. P., Wong K. A., Dunn S., Chen Y. J., Miller S. L., Domin J., O'Bryan J. P. Regulation of neuron survival through an intersectin-phosphoinositide 3'-kinase C2beta-AKT pathway // Mol. Cell. Biol.-2007.-27, N 22.-P. 79067917.

6. Hussain N. K., Yamabhai M., Ramjaun A. R., Guy A. M., Baranes D., O'Bryan J. P., Der C. J., Kay B. K., McPherson P. S. Splice variants of intersectin are components of the endocytic machinery in neurons and nonneuronal cells // J. Biol. Chem.1999.-274, N 22.-P. 15671-15677.

7. Tsyba L., Nikolaienko O., Dergai O., Dergai M., Novokhatska O., Skrypkina I., Rynditch A. Intersectin multidomain adaptor proteins: regulation of functional diversity // Gene.-2011.-473, N 2.-P. 67-75.

8. Kropyvko S. V., Tsyba L. O., Skrypkina I. Ya., Rynditch A. V. Identification and functional analysis of an alternative promoter of human intersectin 1 gene // Biopolym. Cell.-2010.-26, N 2.P. 115-120.

9 Nikolaienko O., Skrypkina I., Tsyba L., Fedyshyn Y., Morderer D., Buchman V., de la Luna S., Drobot L., Rynditch A. Intersectin 1 forms a complex with adaptor protein Ruk/CIN85 in vivo independently of epidermal growth factor stimulation // Cell Signal.-2009.-21, N 5.-P. 753-759.

10. Larkin J. M., Brown M. S., Goldstein J. L., Anderson R. G. Depletion of intracellular potassium arrests coated pit formation and receptor-mediated endocytosis in fibroblasts // Cell.-1983.-33, N 1.- P. 273-285.

11. Grigorian A. L., Bustamante J. J., Hernandez P., Martinez A. O., Haro L. S. Extraordinarily stable disulfide-linked homodimer of human growth hormone // Protein Sci.-2005.-14, N 4.P. 902-913.

12. Yamaguchi N., Fukuda M. N. Golgi retention mechanism of beta-1,4-galactosyltransferase. Membrane-spanning domain-dependent homodimerization and association with alpha- and beta-tubulins // J. Biol. Chem.-1995.-270, N 20.-P. 1217012176.

13. Ichikawa T., Nakayama J., Sakura N., Hashimoto T., Fukuda M., Fukuda M. N., Taki T. Expression of N-acetyllactosamine and beta1,4-galactosyltransferase (beta4GalT-I) during adenoma-carcinoma sequence in the human colorectum // J. Histochem. Cytochem.-1999.-47, N 12.-P. 1593-602.

14. Guipponi M., Scott H. S., Chen H., Schebesta A., Rossier C., Antonarakis $S$. E. Two isoforms of a human intersectin (ITSN) protein are produced by brain-specific alternative splicing in a stop codon // Genomics.-1998.-53, N 3.-P. 369-376.

UDC 577.22

Received 05.06.11 